hypertension and diabetes, using modern therapies that may confer additional cardiovascular benefit (ie, GLP1 inhibitors, SGLT2 inhibitors). Although Taggart and colleagues ${ }^{12}$ provide compelling early anatomic results, the long-term reduction in SVG failure brought on by vesting remains unknown, and subsequent clinical outcomes will need to be ascertained. We are nonetheless grateful and better informed as a result of their mechanistic findings and look forward to longer-term outcomes from the VEST III trial.

\section{References}

1. Caliskan E, de Souza DR, Böning A, Liakopoulos OJ, Choi YH, Pepper J, et al. Saphenous vein grafts in contemporary coronary artery bypass graft surgery. Nat Rev Cardiol. 2020;17:155-69.

2. Moshkovitz Y, Raanani E. The art of saphenous vein grafting and patency maintenance. J Thorac Cardiovasc Surg. 2016;151:300-2.

3. Halabi AR, Alexander JH, Shaw LK, Lorenz TJ, Liao L, Kong DF, et al. Relation of early saphenous vein graft failure to outcomes following coronary artery bypass surgery. Am J Cardiol. 2005;96:1254-9.

4. Lopes RD, Mehta RH, Hafley GE, Williams JB, Mack MJ, Peterson ED, et al; Project of Ex Vivo Vein Graft Engineering via Transfection IV (PREVENT IV) Investigators. Relationship between vein graft failure and subsequent clinical outcomes after coronary artery bypass surgery. Circulation. 2012;125:749-56.

5. Goldman S, Copeland J, Moritz T, Henderson W, Zadina K, Ovitt T, et al. Saphenous vein graft patency one year after coronary artery bypass surgery and effects of antiplatelet therapy. Circulation. 1989;80:1190-7.

6. Kulik A, Abreu AM, Boronat V, Ruel M. Impact of lipid levels and high-intensity statins on vein graft patency after CABG: midterm results of the ACTIVE trial. $J$ Card Surg. 2020;35:3286-93.
7. Kulik A, Voisine P, Mathieu P, Masters RG, Mesana TG, Le May MR, et al. Statin therapy and saphenous vein graft disease after coronary bypass surgery: analysis from the CASCADE randomized trial. Ann Thorac Surg. 2011;92: 1284-90.

8. Kulik A, Ruel M, Jneid H, Ferguson TB, Hiratzka LF, Ikonomidis JS, et al; American Heart Association Council on Cardiovascular Surgery and Anesthesia. Secondary prevention after coronary artery bypass graft surgery: a scientific statement from the American Heart Association. Circulation. 2015; 131:927-64.

9. Kulik A, Le May MR, Voisine P, Tardif JC, Delarochelliere R, Naidoo S, et al. Aspirin plus clopidogrel versus aspirin alone after coronary artery bypass graft ing: the clopidogrel after surgery for coronary artery disease (CASCADE) Trial. Circulation. 2010;122:2680-7.

10. Hage A, Voisine P, Erthal F, Larose É, Glineur D, Chow B, et al. Eight-year follow-up of the Clopidogrel After Surgery for Coronary Artery Disease (CASCADE) trial. J Thorac Cardiovasc Surg. 2018;155:212-22.e2.

11. Deo SV, Dunlay SM, Shah IK, Altarabsheh SE, Erwin PJ, Boilson BA, et al. Dua anti-platelet therapy after coronary artery bypass grafting: is there any benefit? A systematic review and meta-analysis. J Card Surg. 2013;28:109-16.

12. Taggart DP, Gavrilov Y, Krasopoulos G, Rajakaruna C, Zacharias J, De Silva R, et al. External stenting and disease progression in saphenous vein grafts two years after coronary artery bypass grafting: a multicenter randomized trial. $J$ Thorac Cardiovasc Surg. 2022;164:1532-41.e2.

13. FitzGibbon GM, Leach AJ, Keon WJ, Burton JR, Kafka HP. Coronary bypass graft fate. Angiographic study of 1,179 vein grafts early, one year, and five years after operation. J Thorac Cardiovasc Surg. 1986;91:773-8.

14. Kieser TM, Rose S, Kowalewski R, Belenkie I. Transit-time flow predicts outcomes in coronary artery bypass graft patients: a series of 1000 consecutive arterial grafts. Eur J Cardiothorac Surg. 2010;38:155-62.

15. van Domburg RT, Meeter K, van Berkel DF, Veldkamp RF, van Herwerden LA, Bogers AJ. Smoking cessation reduces mortality after coronary artery bypass surgery: a 20-year follow-up study. J Am Coll Cardiol. 2000;36:878-83.

\title{
Commentary: A device solution for the saphenous vein graft's infamous foible?
}

\section{Brittany A. Zwischenberger, MD, ${ }^{a}$ and Mario Gaudino, MD, PhD, $\mathrm{MSCE}^{\mathrm{b}}$}

The choice of graft in coronary artery bypass grafting $(\mathrm{CABG})$ beyond the sturdy left internal mammary artery

From the ${ }^{\mathrm{a} D i v i s i o n}$ of Cardiovascular and Thoracic Surgery, Department of Surgery, Duke University, Durham, NC; and ${ }^{\mathrm{b}}$ Department of Cardiothoracic Surgery, Weill Cornell Medicine, New York, NY.

Disclosures: Dr Zwischenberger is a subinvestigator for US-VEST. Dr Gaudino reported no conflicts of interest.

The Journal policy requires editors and reviewers to disclose conflicts of interest and to decline handling or reviewing manuscripts for which they may have a conflict of interest. The editors and reviewers of this article have no conflicts of interest.

Received for publication April 13, 2021; revisions received April 13, 2021; accepted for publication April 15, 2021; available ahead of print April 20, 2021.

Address for reprints: Mario Gaudino, MD, PhD, MSCE, Division of Cardiovascular and Thoracic Surgery, Department of Cardiothoracic Surgery, Weill Cornell Medicine, 525 E 68th St, New York, NY 10065 (E-mail: mfg9004@med.cornell.edu).

J Thorac Cardiovasc Surg 2022;164:1543-5

$0022-5223 / \$ 36.00$

Copyright (c) 2021 by The American Association for Thoracic Surgery

https://doi.org/10.1016/j.jtcvs.2021.04.045

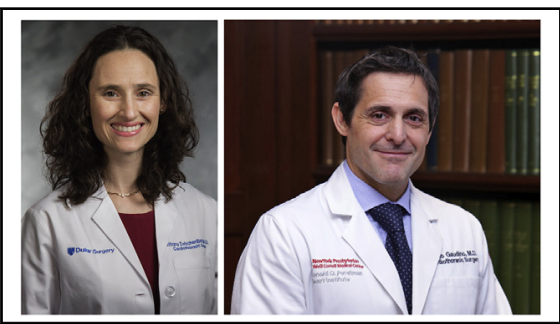

Brittany A. Zwischenberger, MD (left), and Mario Gaudino, MD, PhD, MSCE (right)

CENTRAL MESSAGE

In patients undergoing coronary

artery bypass grafting with

saphenous vein grafting, external

stenting of the vein grafts may

reduce late degeneration.

remains a challenge as surgeons weigh the risks, benefits, and scientific evidence surrounding radial artery, right 
internal thoracic artery (RITA), and saphenous vein grafts (SVG). Although SVG graft patency is disappointing (9\% to $26 \%$ at 1 year, $40 \%$ at 10 years), it remains the most commonly used additional graft.1-5 Confounders abound as investigators attempt to control for the patient factors and surgical techniques contributing to SVG failure, straining statistical methodology and the clinical application of results. The opportunity to simultaneously use patients as test subjects and controls provides valuable insight into any intervention focused on graft patency in CABG.

We congratulate Taggart and colleagues ${ }^{6}$ for undertaking the tenacious problem of late SVG failure through a welldesigned prospective, within-patient, controlled, randomized, multicenter trial evaluating external stenting. The authors included patients $(\mathrm{n}=183)$ who received 2 aortocoronary SVGs and randomized to an external stent to a right or left SVG, leaving the remaining nonstented SVG as an internal control. The endpoints focused on measurements of chronic degeneration, including the Fitzgibbon Patency Scale (FPS) and intravascular ultrasound to assess intimal irregularities (percentage of estimated intimal surface) and degree of intimal hyperplasia, respectively, at 2year follow-up. Of the patent grafts, the primary outcome of FPS grade was significantly different; stented grafts were less likely to demonstrate intimal irregularities (odds ratio, 2.02; $P=.03$ ). Similarly, intimal hyperplasia area and thickness were significantly different between the stented and nonstented grafts $(-22.5 \%$ and $-23.5 \%$, respectively; $P<.001$ ), yet the 2 -year patency rate was similar in the 2 groups $(78.3 \%$ vs $82.2 \% ; P=.432)$.

The authors also focus on the role of harvest technique as a contributor to patency at 2 years, with an open technique $(\mathrm{n}=193)$ demonstrating significantly improved patency compared with an endoscopic technique $(\mathrm{n}=101)$ $(88.6 \%$ vs $65.3 \% ; P<.001)$. Readers should note that the effect of harvest technique does not appear to be a prespecified effect modifier. The large-scale VA REGROUP randomized controlled trial comparing the 2 harvest techniques demonstrated no difference in the composite endpoint of major adverse cardiac events at a similar 2year follow-up, but no imaging evaluation of graft status was performed.

We emphasize that the minimal lumen diameter of SVGs, as reflected by the FPS, is not predictive of future graft failure and is not a significant clinical event. Long-term followup is essential to validate the role of external stenting in SVG patency. A cogent discussion about SVG patency parallels that of a second arterial graft (radial or RITA) in CABG. Should we change practice patterns based on graft patency, a surrogate for long-term patient outcome? Almost 2 decades ago, a randomized-controlled trial using withinpatient controls demonstrated a significantly reduced rate of occlusion on angiography at 1 year in the radial graft group compared with the SVG group $(8.2 \%$ vs $13.6 \%$;
$P=.009) .{ }^{8}$ The positive clinical impact of radial artery grafting in CABG was recently highlighted in a metaanalysis of randomized-controlled trials at a 10-year follow-up with a statistically significant reduction in the incidence of the composite outcome of death, myocardial infarction, or repeat revascularization (hazard ratio, 0.73; $95 \%$ confidence interval, $0.61-0.88 ; P<.001) .{ }^{9}$ However, despite decades of supportive evidence, we continue to debate the utility of the radial artery.

Taggart and colleagues have introduced a novel device to optimize SVG patency, but will the dissemination and implementation of external stents realize its full potential in the mercurial climate of bundled reimbursements and economic pressure? Can external stenting overcome the challenges faced in multiarterial grafting and attain widespread adoption? The external stent is relatively easy to apply to the SVG. In contrast, radial artery and RITA harvest require surgical expertise and may add to the overall operating room time. ${ }^{10}$ Furthermore, the radial artery and RITA are at risk of spasm and may warrant an adjustment in postoperative patient management, minimizing inotropes and adding oral calcium-channel blockers. ${ }^{11}$ The simplicity of the external stent is enticing and may facilitate adoption in the surgical community, although cost will be an important issue. The study by Taggart and colleagues is an example of an innovative, simple device solution for a pervasive limitation of SVGs in CABG, and we look forward to future studies inVESTigating the external stent.

\section{References}

1. Goldman S, Zadina K, Moritz T, Ovitt T, Sethi G, Copeland JG, et al; VA Cooperative Study Group \#207/297/364. Long-term patency of saphenous vein and left internal mammary artery grafts after coronary artery bypass surgery: results from a Department of Veterans Affairs Cooperative Study. J Am Coll Cardiol. 2004; $44: 2149-56$.

2. Alexander JH, Hafley G, Harrington RA, Peterson ED, Ferguson TB Jr, Lorenz TJ, et al; PREVENT IV Investigators. Efficacy and safety of edifoligide, an E2F transcription factor decoy, for prevention of vein graft failure following coronary artery bypass graft surgery: PREVENT IV: a randomized controlled trial. JAMA. 2005;294:2446-54.

3. Fitzgibbon GM, Kafka HP, Leach AJ, Keon WJ, Hooper GD, Burton JR. Coronary bypass graft fate and patient outcome: angiographic follow-up of 5,065 grafts related to survival and reoperation in 1,388 patients during 25 years. $J$ Am Coll Cardiol. 1996;28:616-26.

4. Schwann TA, Tatoulis J, Puskas J, Bonnell M, Taggart D, Kurlansky P, et al. Worldwide trends in multi-arterial coronary artery bypass grafting surgery 2004-2014: a tale of 2 continents. Semin Thorac Cardiovasc Surg. 2017;29:273-80.

5. Willemsen LM, Janssen PWA, Peper J, Soliman-Hamad MA, van Straten AHM, Klein $\mathrm{P}$, et al. Effect of adding ticagrelor to standard aspirin on saphenous vein graft patency in patients undergoing coronary artery bypass grafting (POPular CABG): a randomized, double-blind, placebo-controlled trial. Circulation. 2020;142:1799-807.

6. Taggart DP, Gavrilov Y, Krasopoulos G, Rajakaruna C, Zacharias J, De Silva R, et al. External stenting and disease progression in saphenous vein grafts two years after coronary artery bypass grafts: a multicenter randomized trial. J Thorac Cardiovasc Surg. 2022;164:1532-41.e2.

7. Zenati MA, Bhatt DL, Bakaeen FG, Stock EM, Biswas K, Gaziano JM, et al; REGROUP Trial Investigators. Randomized trial of endoscopic or open vein-graft harvesting for coronary-artery bypass. $N$ Engl $\mathrm{J}$ Med. 2019;380:132-41. 
8. Desai ND, Cohen EA, Naylor CD, Fremes SE, Radial Artery Patency Study Investigators. A randomized comparison of radial-artery and saphenous-vein coronary bypass grafts. N Engl J Med. 2004;351:2302-9.

9. Gaudino M, Benedetto U, Fremes S, Ballman K, Biondi-Zoccai G, Sedrakyan A, et al; RADIAL Investigators. Association of radial artery graft vs saphenous vein graft with long-term cardiovascular outcomes among patients undergoing coronary artery bypass grafting: a systematic review and meta-analysis. JAMA. 2020;324:179-87.
10. Gaudino M, Kurlansky P, Fremes S. The use of the radial artery for coronary artery bypass grafting improves long-term outcomes: and now what? J Thorac Cardiovasc Surg. November 10, 2020 [Epub ahead of print].

11. Gaudino M, Benedetto U, Fremes SE, Hare DL, Hayward P, Moat N, et al RADIAL Investigators. Effect of calcium-channel blocker therapy on radial artery grafts after coronary bypass surgery. J Am Coll Cardiol. 2019;73: 2299-306. Erratum in: J Am Coll Cardiol. 2019;74:597-9. 